\title{
A Study of Former Japanese Prime Minister Abe's Speaking Style in 2020: Listener-Oriented or Speaker- Oriented?
}

\begin{abstract}
By Shoji Azuma*
Generally speaking, politicians sometimes communicate in a manner that may be considered untrue or even inappropriate in various political situations. One reason for this is the simple but crucial fact that politicians often talk in a manner that is excessively focused on themselves rather than on their listeners. Political officials, it seems, really enjoy talking about what they plan to do and accomplish during their tenure, but less so about what the general public really wants to hear. Speaking more about themselves and less about their constituents, demonstrates that many politicians are clearly speaker-oriented and not listener-oriented. Japan's former Prime Minister, Shinzo Abe, is an example of a politician who often uses a speaker-oriented approach. Through the lens of speaker versus listener orientation, this paper examines Abe's speaking style in various contexts, including Abe's comments during several political scandals, as well as Abe's speeches to constituents and global audiences. By studying Abe's communication style, we find that politicians may maximize their effectiveness when they orient their speech to listeners, instead of focusing on themselves. The primary data for this study comes from the National Diet Session documentation files provided by the Japanese government, as well as major newspaper articles.
\end{abstract}

Keywords: Japan, listener-oriented, solidarity, speaker-oriented, speech orientation

\section{Introduction}

Japanese political rhetorical study in the postwar period has not been examined extensively except a few cases in sociolinguistics (Maynard, 1994; Ikeda, 2009; Azuma, 2010). In the present paper, we address the question of how rhetorical usage influences Japan's political landscape. In particular, we take an approach that there are two ideas in speech orientation (e.g., Makino, 1983; Azuma, 2014): One is to orient our speech toward ourselves, as if talking only to ourselves. In such a case, when we talk, although we are aware that other people are listening, we might consider it simply as audible internal dialogue with ourselves. We call this the speaker-oriented approach. The other approach takes into account the listeners or addressees. In such a case, our speech is oriented to others and not just the speaker. We call this the listener-oriented approach ${ }^{1}$.

This speaker- versus listener-orientation is critical to understanding how politicians behave, particularly in the speech behavior of Japan's prime minister, Shinzo Abe, who is the focus of this study. Generally speaking, a commonly

\footnotetext{
*Professor, Department of World Languages and Cultures, University of Utah, USA.

${ }^{1}$ For further discussion, please see Makino (2018).
} 
recognized perception is that politicians often talk about themselves (i.e., speakeroriented) without referring to the general public's wants and needs. Prime minister Abe is not an exception to this rule. His style is most often speaker-oriented rather than listener-oriented. If Abe would consider more frequently what his addressees or the general public want to hear, then his speech would become listener-oriented.

Because Abe very often pursues what he, himself, wants to accomplish, and not what the general public wants to know or achieve, his constituents are familiar and frustrated with his speaker-oriented approach. Therefore, the listener orientation is missing from Abe's speech. One of the important aspects of a listener-oriented approach is the fundamental issue of kуооуи gengo or shared language. Put differently, shared language is a willingness to share one's own feelings with others and sense a mutual closeness with them. In the political arena, politicians can accomplish this by finding common ground with the general public, and by sharing a similar approach to organize and achieve the same goal, value or idea ${ }^{2}$. Instead of dividing into separate groups and disengaging with one another, finding common ground enhances the likelihood for achieving a shared goal.

\section{Method}

In the present study, I will examine Abe's speaking style as observed in relevant newspaper articles (e.g., Asahi, Mainichi, Yomiuri, Sankei, Jiji Shinpo and Japan Times newspapers), government documents (e.g., Japanese National Diet session), a joint session of Congress in the United States, as well as other relevant materials. I adopt a rhetorical approach in studying the speaking style of Abe, examining how he expressed his ideas, policies and strategies in order to persuade and convince his audiences (e.g., politicians and the general public). Specifically, I will focus on whether Abe used a speaker-oriented style or a listener-oriented style in his speeches. For example, did Abe try to connect with his audience by expressing feelings which his audience also shared? Or, alternatively, did Abe focus on his own personal inclinations (not shared by the audience) in his speaking style? What did he think about his own speeches? What did "speaking" mean to him?

The sections below contain an analysis of Abe's self-oriented speech style. First, a short description of Abe's background is provided, followed by a general overview of his political scandals. Then, we will examine, in greater detail, two aspects of the cherry blossom festival scandal: the cherry blossom viewing party and the bribery accusations in the National Diet. Finally, we will look at an example of Abe's listener-oriented approach and, before summarizing conclusions, review the recent example of the COVID-19 press conference by Abe in Japan.

\footnotetext{
${ }^{2}$ Among many experts, Jacques Attali, the French economic theorist argues for the altruism (rita shugi) by stating that "the real legitimacy of democratic power tomorrow is empathy." Please see https://asi a.nikkei.com/Editor-s-Picks/Interview/Technology-to-reign-supreme-after-the-coronavirus-JacquesAttali. [Accessed 20 April 2020]
} 


\section{Prime Minister Shinzo Abe}

Who is Shinzo Abe? Abe is a Japanese politician and the current prime minister of Japan, since 2010. He previously served as the Chief Cabinet Secretary (Kanboo Chookan) from 2005 to 2006, and as prime minister from 2006 to 2007, making him the longest-serving prime minister since the office was created in 1885. If Abe continues in his post until his term expires on September 30, 2021, he will have served for a total of more than 3,500 days, about $91 / 2$ years.

Abe was first elected to the House of Representatives in 1993. Later appointed Chief Cabinet Secretary, he was extremely popular with the electorate, including opposition lawmakers. Confirmed the prime minister in 2006, at the age of 52, he was Japan's youngest post-war prime minister, and the first to have been born after World War II. However, in September 2007, he suddenly resigned, citing health reasons.

Yet, in September 2012, Abe staged an unexpected political comeback and has been prime minister since that time. A conservative, whom political commentators have widely described as a right-wing nationalist, he advocates revising Article 9 of the Japanese Constitution to allow Japan to maintain their own military force. $\mathrm{He}$, and other conservatives, see the constitution, which forbids Japan from using force to settle international disputes, as an outdated constraint on Japan's ability to defend itself against a nuclear-armed North Korea and a more assertive China. Despite several cronyism scandals and failing to enact structural reforms, such as increasing the number of women in senior public and private roles, many analysts agree that Abe has benefited from a weak and divided opposition and a desire for stability among voters.

Over the course of the decade, Abe's tenure has made Japan an island of political stability even as other advanced industrial democracies have suffered from weak, unpopular, and short-lived governments. Abe's strong endorsement of governmental economic policies, which pursue monetary easing, fiscal stimulus, and financial reforms - sometimes called "Abenomics" has contributed to such stability ${ }^{3}$.

\section{Political Scandals}

Recently, amid voter concerns about an economic slowdown, Abe showed little appetite for celebration as he fielded questions over a fresh political scandal in the Diet. Abe has denied any wrongdoing as he faces accusations that his office broke campaign laws by partially paying for supporters that he personally invited to a reception at the government-funded cherry blossom festival in Tokyo. However, a poll by the Asahi Shinbun, which has a readership of over 10 million, showed $68 \%$ of respondents were unconvinced by his explanations (Asahi Shinbun, June $24,2019)$. Some commentators have even argued that this event is a significant

\footnotetext{
${ }^{3}$ Abe and his government unveiled a comprehensive package known as Abenomics to revive the Japanese economy from two decades of deflation, all while maintaining fiscal discipline.
} 
blow to his political career, and the chances of him achieving the goals of his party, including constitutional reform, is very low.

Over the course of Abe's time in office, it is easy to identify numerous political scandals, perhaps, sadly, even too many to count ${ }^{4}$. However, in past months, backlash from an angry and confused public as well as opposition parties, has finally forced Abe to take responsibility of a more prominent role. Nevertheless, his clumsy efforts have only succeeded in deepening the biggest political crisis of his more than seven consecutive years in office.

One example of Abe's political scandals took place during the year 2019, when a pair of cabinet ministers resigned. Due to general election discrepancies in the Hiroshima district, Katsutoshi Kawai (minister of law) stepped down. In addition, Isshuu Sugawara (minister of trade, economy and industry) resigned because of allegations that he received bribes from his supporters. Abe insisted that these politicians provide an explanation to the public, but neither have done so. Furthermore, a member of Abe's political party, Mr. Tsukasa Akimoto, the vice minister of transportation, has been linked to bribes from a Chinese gambling company. Again, though requested, no public explanation has ever been made to the public. Despite these serious allegations against members of his cabinet, Abe made only brief appearances at strategy meetings, and spent his evenings wining and dining with friends and cabinet ministers.

Asahi Shinbun, wrote a recent editorial about the current state of the Japanese National Diet (February 13, 2020). The title reflects the newspaper's critical viewpoint "kooryoo taru kokkai, Abe shushoo no sekinin wa omoi" (Devastating Diet meetings, Abe has been solely responsible for the dissatisfactory gatherings). The essay claims the following:

(1) Abe shsuhoo no itakedaka nai hanron ya yaji, shidoro modoro no kakuryoo tooben. Kensetsuteki na giron o tsuujite yoriyoi ketsuron o michibikidasu, sonna "genron no fu" no aru beki sugata kara hodo tooi kookei ga tsuzuite iru koto ni azen to suru.

(Prime minister Abe's arrogant and aggressive approach, irregular comments, and the unspinning of lawmakers' opinions is extremely disappointing. Our National Diet and these unpleasant debates are far removed from the reasonable question and answer sessions we have come to expect.)

One lawmaker, Kiyomi Tsujimoto, of the Constitutional Democratic Party of Japan, was quoted during a Diet session as stating the following to prime minister Abe (Asahi Shinbun, February 17, 2020):

\footnotetext{
${ }^{4}$ Some people argue that there have been some sontaku or conjecture/surmise among government officials and relevant individuals. For example, in the so-called Kagoike-scandal, this sontaku was used with respect to the altered documents related to the discontinued sale of state-owned land to a school operator, Kagoike, with ties to Abe's wife, raising the possibility of a cover-up. See also the book authored by Abe's wife (Abe, 2015) which discusses about the speaker herself. In addition, the President Online has carried an article about Abe. (https://president.jp/articles/-/34761?page=2) (April 20, 2020).
} 
(2) Soori sankoo ni mooshi agemasu. Tai wa atama kara kusaru to iu kotoba o gozonji desu ka? Koko made kitara genin wa tai no atama. Atama o kaeru shika nain jya nai desu ka? Sorosoro soori jishin no makuhiki da to omoimasu.

(May I mention a reference to you, our Prime Minister. Do you know of the saying, "The sea bream rots from the head?" If we have come to this point, we can say that the cause is the head. The only option is to change the sea bream's head to avoid everything going bad, don't you think? I believe it is about time for your political term to come to an end.)

Abe was very upset by Tsujimoto's negative comment comparing him to the head of a sea bream, and commented, to himself under his breath, "imi no nai shitsumon da yo" (what you are saying is meaningless). This statement, although spoken to himself, was clearly heard by the entire Diet attending the session (incidentally, Abe's muttering to himself was deleted from the official government record). This impulsive personal reaction, not meant to be heard by all, suddenly created a firestorm among opposition lawmakers. Viewed as Abe's belittling of an opposition lawmaker during the Diet session, the utterance was denounced as uncivil and inappropriate for a prime minister.

This incident has only reinforced Abe's image as having hostility towards opposition parties and exhibiting a blatant disregard for the legislature. Although Abe made an official apology, saying "I apologize for my irregular remarks; I will discipline myself as prime minister and refrain from making such remarks," his demeanor seemed unrepentant, and he still appeared and acted defiant. Since then, he has continued to succumb to the temptation to heckle opposition legislators, provoking on-going criticism from various quarters. Gerald Curtis, a professor emeritus of political science at Columbia University assured that whoever will succeed Abe "will face a skeptical, distrusting public." (New York Times, March $10,2020)^{5}$.

\section{Cherry Blossom Viewing Party}

Let us examine the details of the cherry blossom viewing scandal. Cherry blossom viewing is considered one of the most important and national spring events in Japan and attracts a large number of people to Tokyo, the nation's capital. A source of national pride, the blossoms represent the fragility and fleeting beauty of life. A common social practice is to hold a cherry blossom viewing party during the short season. One such party was held at the highly respected ANA InterContinental Tokyo hotel. Considered one of the leading hotels in the Akasaka area, downtown Tokyo, it has received both the World Travel Award and World Luxury Hotel Award; prestigious awards that recognize excellence in the travel, tourism and hospitality industries.

For the present paper, the most controversial question is whether Abe's office spent national budget funds to invite and entertain his supporters at the cherry blossom festival events. According to Abe and his office staff, the hotels, including

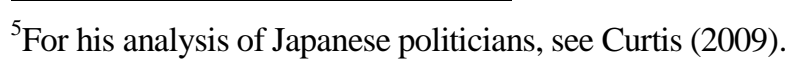


the ANA Intercontinental Hotel, did not issue any quotes or detailed invoice statements, yet the price, set by the hotels, was 5,000 yen per person. Typically, the cost for such an event would be at least 15,000 yen, far exceeding the 5,000 yen price. In other words, it appears that each Abe supporter received a benefit in the form of a discount of 10,000 yen (approximately USD \$95 per person), which could be viewed as a "bribe" or favor paid to such supporters to attend party events.

To put it in more straightforward terms, it does not make economic sense for the hotel, which could normally charge 15,000 yen per person during such time of high demand, to only charge 5,000 yen per person. By doing so, the hotel would lose up to a total of 3,000,000 yen or more, depending on the number of attendees. It is only plausible to infer that the hotel's loss would somehow be compensated by the hosting party, the Abe-led political government. Such an occurrence, if paid by Abe's office using the national budget funds, would be a clear misuse of public funds and a potential violation of Japan bribery laws, even if the attendees participated without knowledge of the benefit or compensation. In sum, each attendee may have unwittingly received a benefit of at least 10,000 yen by Abe's office and the national government.

Abe has argued that the party fee (5,000 yen) was collected from each participant at the entrance of the venue by his office staff, that then provided a receipt issued by the hotel. Abe maintains that after all money was collected by his staff, it was then turned over to the hotel. He argues that because of this, no income or outlays were processed through his office. It is not clear how the hotel came up with 5,000 yen fee, given that the total number of attendees at the party was unknown. The inference is clear that someone had to pay the difference to the hotel, and Abe's office and the Japanese government are the prime suspects.

In short, Abe claims there is nothing wrong in organizing and conducting the cherry blossom viewing parties for attendees. According to some newspapers, this type of cherry-blossom event has been held annually for the past seven years, starting in 2013.

However, as additional evidence, one lawmaker, Kiyomi Tsujimoto, claimed that she received a detailed e-mail response from the ANA Intercontinental hotel on the morning of 17 February 2020. The following are the details of the communication between the hotel and Tsujimoto. This information is drawn from the Japanese National Diet session files, as well as national news outlets such as the Asahi, Mainichi, and Sankei newspapers.

(3) 2013 nen ikoo no 7 nen kan ni ki hoteru de hirakareta party and reception events ni tsuite oukagai shimasu. Jyooki ni tsuite ki hoteru ga mitumorisho ya seikyuusho o shusaisha gawa ni hakkoo shinai keesu ga atta de shoo ka? (Tsujimoto)

(Let me ask about the parties and events which were held at your hotel during the past 7 years, beginning in 2013. During such period, have you ever had a case when you have not issued an estimate or receipt to the hosting agency?)

(4) Gozaimasen. Shusaisha ni taishite mitsumorisho ya seikyuu shoomeisho o hakkoo itashimasu. (Hotel)

(No. We always issue an estimate or receipt to the hosting agency.) 
This statement clearly shows that the hotel has decisively stated they always issue either a receipt or a cost estimate to an agency in connection with party events. Starkly refuting Abe's explanation, this statement is significant. Given this clear statement, Tsujimoto once again asked a slightly different question to the hotel. Observe the following query and answer.

(5) Jyooki ni tsuite kojin dantai o towazu, ki hoteru no tanntoosha ga kingaku nado o tegaki shi, atena wa kuuran no mama ryooshuusho o hakkoo shita keesu wa atta de shoo ka? (Tsujimoto)

(With respect to the above mentioned period, regardless of whether it was an individual or a political group, have any of your hotel members ever written a memo of receipt in which the addressee space was left blank?)

(6) Gozaimasen. Hei-hoteru ga hakkoo suru ryooshuusho ni oite, atena o kuuran no mama hakkoo suru koto wa gozaimasen. (Hotel)

(We never do that. We never issue a receipt with the addressee space left blank.)

The hotel's response further clarifies, in precise terms, that the hotel never issues a receipt without specifying an addressee. Again, this is a clear contradiction of Abe's explanation. This is quite shocking and different from what we would tend to expect from the prime minister of Japan. Ultimately, these actions raise a clear discrepancy which, if valid, may point to a potential violation of Japan law.

Later, Abe insisted that the answers to Tusjimoto, as listed in (3) through (6) above, were about "general rules" (ippan teki) and not about any "specific case" (tokubetsu), such as this particular incident. Hence, Abe concluded that there has been no inconsistency between his previous statements and the hotel's response to Tsujimoto. Can we accept Abe's remarks at face value? Many viewers including the opposition parties have fundamental doubts and have asked him to contact the hotel again, in writing, and make their response public. However, Abe has simply rejected their request.

How is it possible for Abe to take no active efforts to clarify the allegations against him? One possible answer to this question is analyzing and understanding the way the prime minister speaks. In particular, all of his actions, comments and statements referenced above from the cherry blossom festival scandal, lend support to the conclusion that Abe uses a self-oriented approach.

\section{Accusation of Baishuu ("Bribe")}

We next examine Abe's comments and statements in response to bribery accusations made during the national Diet sessions as further evidence of his selforiented approach. Takahiro Kuroiwa, a lawmaker belonging to the Constitutional Democratic Party of Japan, spoke to Abe during one of the Diet sessions. Kuroiwa became very upset by the fact that Abe's personal secretary (hishokan) was speaking to Abe while Kuroiwa took the stand to ask questions about the cherry blossom party. Kuroiwa felt ignored by Abe and took great offense. Observe the 
sequence of Kuroiwa's comments and Abe's reply. The data is taken from the National Diet session stenograph.

(7) Shinrai ni urazuke rareta baishuu desu yo. Datte, Abe soori, toozen, kore rieki kyooyo desu yo. (Kuroiwa)

(It is a bribe based on the trust between you and the hotel. Prime minister Abe, this is a clear case of what I call a "bribery.")

Kuroiwa clearly alleged that the prime minister had "bribed" the participants by providing them a monetary benefit. Suddenly, at this point in the conversation, Kuroiwa noticed Abe's secretary quietly but visibly making verbal comments to the prime minister. This fact agitated Kuroiwa, and he abruptly and quite openly condemned Abe, using an extremely loud voice, which could be heard by the entire Diet. Observe Kuroiwa's statements below.

(8) Soko urusai. Soko shiro, urusai, kankei naidesho, soko, soko kankei nai kara, nande Abe sanshika kotaerarenaikara, nande, okashii deshoo, soko kankei nai, soko.

(Over there, you are noisy, you, in white, you are indeed noisy. You have nothing to do with this. Over there, you have nothing to do with this. Abe is the only person who can answer, why do you speak? Are you crazy? Over there, you have nothing to do with this.)

Abe's secretary speaking to the prime minister during Kuroiwa's questioning without having received permission to speak in the Diet session, was a glaring breach of Diet protocol. Abe's reply is noteworthy in light of speaker-oriented speech. Observe what Abe said to Kuroiwa (and the general public, who were listening to the live Diet session on television).

(9) Maa, hishoka wa samazama na kikai ni desu ne. Watashi ni adobaisu suru koto wa arimasu yo. Soreni taishite donaru to iu no wa desu ne. Ijyoo na taioo desu yo. Sore wa yappari okashii desu yo. Sore kurai atarimae jyaa nai desu ka.

(Well, a secretary takes an occasion and tries to give some advice to me. And you get angry and yell at me like you have just done in front of me. It is unbelievably rude. What you have done is absolutely unthinkable. What I am telling you is a simple fact.)

In response to Kuroiwa's abrupt comment, Abe scolds Kuroiwa by suggesting that his secretary had done nothing wrong. Then Abe continued his strong response. Observe his next sentence.

(10) Mattaku sonn na koto wa nai wake deshite, mattaku baishuu to iu kyooretsu na kotoba o tsukau. Mattaku bakagete arienai kotoba deshite. (emphasis added)

(It is not like that at all. Good grief, you use the utterly crazy word, "bribery." It is a completely rude and unthinkable word (i.e., bribery).)

Abe expressed his anger and complete dissatisfaction with Kuroiwa. The fact that Kuroiwa had chosen to use such a strong word - bribery - in his questioning of Abe was countered with Abe likewise using a severe term - kyooretsu (utterly crazy) - to describe Kuroiwa. 
In essence, Abe's response supports his speaker orientation approach. Abe replied to Kuroiwa by expressing what mattered to Abe, and not taking into account the feelings of the listener. Abe spoke of his own anger and feelings of condemnation without empathizing how Kuroiwa and the general public might feel about what he had done. Interestingly, he has never offered an apology for his secretary's behavior during the Diet session. No explanation or justification has ever been made public, except his comment that the word bribe is kyooretsu (utterly crazy) and unthinkable for him.

\section{Abe's Listener Orientation}

So far, we have examined examples of Abe's speech style which support the speaker-oriented approach. However, are there examples of Abe's speech which reinforce a listener-oriented method? While Abe's style seems to be speakeroriented the majority of the time, accompanied by his strong determination not to resign as prime minister (Asahi Shinbun, April 2, 2020), we have seen some occasions when Abe temporarily becomes a listener-oriented speaker. ${ }^{6}$ One clear example of this was when he traveled abroad to the U.S. in 2015 to give a speech at a joint session of Congress in Washington D.C. We will examine his speech style on this occasion from the media accounts reported in the Japan Times newspaper (Japan Times, April 30, 2015).

On 29 April 2015, Abe made an historic, first ever address by a Japanese prime minister to a joint session of the U.S. Congress. In his speech, Abe focused on the long-term relationship between Japan and the U.S., going back to when the two countries were enemies during World War II. During his speech, Abe recognized several dignitaries in the audience and made the following statements:

(11) Ladies and gentlemen, in the gallery today is Lt. Gen. Lawrence Snowden. Seventy years ago in February, he landed on Iōtō, or the island of Iwo Jima, as a captain in command of a company. In recent years, General Snowden has often participated in the memorial services held jointly by Japan and the U.S. on Iōtō. He said, and I quote, "We didn't and don't go to Iwo Jima to celebrate victory, but for the solemn purpose to pay tribute to and honor those who lost their lives on both sides."

In a dignified manner, Abe introduced Snowden who had been the U.S. commander during the Iwo Jima military campaign. Abe honored Snowden as a capable commander to lead the U.S. at such time of war. At the session, a Japanese individual was sitting next to Snowden. Observe Abe's next comments.

(12) Next to General. Snowden sits Diet member Yoshitaka Shindo, who is a former member of my Cabinet. His grandfather, General Tadamichi Kuribayashi, whose valor we remember even today, was the commander of the Japanese garrison during the Battle of Iwo Jima.

\footnotetext{
${ }^{6}$ Taniguchi (2018) discusses Abe's communication style as his speechwriter.
} 
Essentially, the visual juxtaposition of Snowden, the U.S. commander at the island, and the grandson of Mr. Kuribayashi, the Japanese commander during the same campaign, is compelling. (Incidentally, Mr. Kuribayashi died at Iwo Jima at the end of the war.) $)^{7}$ Abe continues his speech as follows:

(13) What should we call this, if not a miracle of history? Enemies that had fought each other so fiercely have become friends bonded in spirit.

To Abe and all the members of the U.S. congress, this was a significant and profound moment of his speech. Two past enemies, now unified in peace, sitting side by side in the gallery of a joint session of the U.S. congress, had historical implications.

It is important, nevertheless, in our analysis of Abe's speech, to make the distinction that Abe was speaking to U.S. politicians, not Japanese politicians. In other words, this example of Abe as a listener-oriented speaker occurred in a different context -- Abe was acting as an American politician and not as a Japanese politician. A Japanese politician would never invite members of the public to a session of the Diet and introduce them to the legislators, as Abe did at the U.S. Congress. Abe, in fact, espoused American customs and behaviors for this historical speech. Abe's adoption of the listener-oriented style also helps explain why the audience so enthusiastically accepted the speech. He oriented his remarks to the listeners and their needs. If he had not done so, and did not personalize his remarks by introducing the visitors, it is easy to conclude that his speech would not have received the same level of acceptance by the U.S. audience.

Having evaluated this rare instance of Abe's listener-oriented approach, let us examine briefly, other Japanese prime ministers who exhibited listener-oriented traits. For example, Kakuei Tanaka (1918-1993) was a very popular prime minister. Often called a "bulldozer with a computer," he was a smart, talented, and powerful "country builder" at a time when the country needed such a politician. Active in building highways, bullet trains, dams, and other infrastructure, he paid close attention to what local people really needed in their hometowns. A clear example of a popular listener-oriented speaker, he fully understood and shared the values of his constituents. More recently, Junichiro Koizumi (1942-), was considered a "strange politician" (henjin) and a "one phrase" (wan fureezu) leader known for his concise speech. However, he was extremely enthusiastic about political reform and restructuring the economy (called yuusei mineika -- post office reforms) when the country really needed a diversified approach to economy building. One unique aspect of his policies was his ability to produce his own political agenda, which was shared by the general public (kyooyuu gengo -- shared language). Because he made an effort to fully understand the ideas and values of his constituents and acted to carry them out, Koizumi can be viewed as adopting a listener-oriented approach. From these two examples, we can posit that sharing and understanding the views and values of the general public will strengthen a politician's ability to communicate with, and gain the support and approval of the people, helping to further his or her political agenda.

\footnotetext{
${ }^{7}$ The film "Letters from Iwo Jima" directed by Clint Eastwood deals with this subject matter.
} 


\section{Abe's Press Conference on COVID-19}

Let us now turn to studying another example of Abe's speech, as reflected in a recent press conference concerning the COVID-19 crisis in Japan. In the U.S. and many other countries, it is common for a political leader to use prepared written materials, and even a prompter, when speaking at a press conference or other formal events. For example, the current U.S. president often uses a teleprompter placed in front of him when conducting a press conference. These media devices help a political leader to ensure his or her speech is accurate, concise and consistent with the administration's agenda. Nevertheless, when the speaker delivers the message apart from prepared written remarks, bringing emotion, enthusiasm and conviction to the fore, the speaker's communication style is enhanced and seems to be better accepted by the audience,. In essence, adopting a listener-oriented approach is a key to its political success. 8

Under the circumstances of a national emergency, this aspect of emotive and enthusiastic communication becomes critical. Using a speaker versus listeneroriented analysis, let us examine how Abe behaved at a recent press conference during the COVID-19 crisis in Japan. Did his speech convince the audience or move them emotionally? Given that a listener-oriented style pays attention to the listener's needs, and often enables an emotional interpersonal experience between the speaker and the listener, was Abe successful in achieving such results with his audience?

On 7 April 2020, Abe gave his first press conference to explain a "declaration of a state of emergency" in Japan, relating to the COVID-19 pandemic. Upon close examination of the video of this speech, we notice that Abe was careful to maintain eye contact with the media and the audience, more so than usual. It also appears that he used long pauses more frequently than normal. Nonetheless, it is clear that his speech as a whole was not convincing enough to move people emotionally. He continued to adopt a speaker orientation by using extremely polite expressions when addressing the audience, instead of more aggressive and authoritative forms. Although we might expect such behavior in Japanese culture at such a very formal conference as this occasion, the need to urgently and effectively communicate with the audience under these circumstances becomes more important than abiding by cultural norms. After all, the subject of the conference is the declaration of a state of emergency for the country in a national crisis. Abe's speech fails to meet this expectation. Observe some of his expressions below, which support his speaker-oriented approach (see also Okamoto, 2020).

\footnotetext{
${ }^{8} 47$ News (including the Kyodo Press) reports that Abe's government always blames others (the Japanese people) instead of blaming the government itself. Please see https://headline s.yahoo.co.jp/hl?a=20200502-00000001-yonnana-soci\&p=1 (Retrieved on May 2, 2020). Asahi Shinbun also reports that the Japanese government abides the concept of Jishu Yoosei (voluntary request) demanding a request to only go out outside for essential things without any sanctions attached to the request. Please see https://digital.asahi.com/articles/A SN4Z7F2B N4ZUTFK00K.html?ref=m or_mail_topix 1. [Accessed 3 May 2020]
} 
(14) Seikatsu no iji ni hitsuyoo na baai o nozoki,midari ni gaisyutu shinai yoo yoosei subeki to kangaemasu.

(I think that we should ask you not to go out except when you need to do so by necessity.)

(15) Gaishutsu jishoku o onegai shimasu.

(We ask you to avoid going out.)

(16) Mittsu no mitsu o sakeru koodoo o tettei shite itadaku yoo aratamete onegai itashimasu.

(We humbly ask you to take action to avoid the three "high-density" areas (i.e., closed spaces, crowded places, a close-contact setting.)

In each sentence, we see the clear example of the Japanese linguistic style of politeness. Simply put, his statements were too polite in this context of urgent necessity (Azuma, 2019). Instead, Abe should have used expressions that were more decisive, full of confidence and unwavering determination. Examples might include:

(17) Gaisyutu shinai yoo yoosei shimasu.

(We ask you not to go out.)

(18) Gaishutsu o jishuku shite kudasai.

(Please do not go out.)

(19) Mittsu no mitsu o sakeru koodoo o tette kudasai.

(Please actively avoid the three "high-density" areas.)

In each sentence, the final particle is simplified, and the linguistic form is more direct, like a strict order. For example, in (17), yoosei shimasu (we ask you) is very straightforward and directly asks the listeners to follow the command. In its original expression in (14), it is unnecessary to say seikatsu no iji ni hitsuyoo na baai o nozoki,midari ni (not to go out except when you need to do so by necessity), given that the statement needs to be a strong "order" expressed by the leader of the country in crisis. Abe may feel that the expression in (14) is a Japanese way to communicate his intended meaning, however, it is also a manifestation of his speaker-oriented approach, and it will never reach the listeners so that it convinces and moves them emotionally. In an emergency situation, it is an absolute necessity for a political leader to connect with listeners in an interpersonal way by using the most reasonable and shortest expression, as reflected in (17). Likewise, in (18) and (19), the simplest expression is used to convey the order. In each case, we recognize that the listener-oriented approach is an extremely important tool for convincing and emotionally connecting with an audience?

Another example from Abe's speech is when he briefly discusses a "lock down." A "lock down" is a political directive to completely close the city in a bid to stop the spread of COVID-19. For example, in the UK, police officers are able

${ }^{9}$ Decker (2008) gives various examples from business environments. 
to fine or even arrest those ignoring a stay-at-home order or "lock down," Abe insists that Japan will never take "lock down" measures. Observe his comment during the conference.

(20) Konkai no kinkyuu jitai sengen wa kaigai de mirareru yoo na toshi fuusa lock down o okonau mono de wa mattaku arimasen. So no koto wa meikaku ni mooshi agemasu.

(This declaration of a state of emergency has nothing to do with any so-called city disclosure or lock down as seen in other countries. I firmly state this fact.)

In this example, Abe clearly states that the "state of emergency" does not equate to closing the city or a "lock down." Citizens can still move freely as they usually do, although they are not encouraged to do so. The idea of "lock down" has never been discussed or implemented under Japanese governmental policies. The Japanese Constitution prohibits unwanted government intervention in the ordinary life of Japanese citizens, protecting freedom of speech and movement within the country. This overriding principle stems from historical government abuses during World War II, when the government forced citizens to fight in the war with little to no compensation. Therefore, dissimilar to the efforts used in many other European and North American countries, the Japanese government has not forced their citizens to endure "lock down" procedures.

Given Abe's statement, we must ask whether the listeners will indeed follow Abe's instructions. In particular, he does not mention any penalty or fine for not following the stay-at-home policy. Abe's only instruction was asking people to stay-at-home. No additional consequences for violating the instruction were mentioned. From our analytical perspective, we may say that this is an example of a speaker-oriented approach because Abe is not responding to the needs or questions of the people at all.

Under emergency circumstances we see that a speaker needs to be listeneroriented, instead of speaker-oriented. Abe paid no attention to this important linguistic mechanism and as a result, most of the media and the general public were quite disappointed or at least not emotionally convinced. One communication specialist, Okamoto (2020) argues that Abe's speech was "without any blood" and his style was "sluggish and bureaucratic" (Okamoto, 2020). This similar analysis has also been expressed by other media such as the Asahi, Yomiuri and Sankei newspapers.

On 16 April 2020, Abe conducted another press conference concerning the COVID-19 crisis. At this event, he announced the payment of 100,000 yen (about USD \$900) to every single Japanese citizen to assist them in surviving the crisis. While a welcome gesture, this announcement constituted a remarkable shift from his previous decision to provide 300,000 (about \$2,700) to each household with reduced income. It is noteworthy that this political shift, which benefits government finances by about three times the original plan, was decided due to pressure from his allied political party, Komeito (Clean Government Party). This party insisted on the 100,000 yen proposal for every Japanese citizen (see also newspapers including Asahi, Mainichi, Yomiuri, and Jiji Shinpo). It is significant that the shift was not initiated by any pressure from the general public, but by Abe's allied political 
party, Komeito. Abe seems to have paid more attention to his own party interests as well as those of allied parties and as a result, lost the opportunity to listen and connect with the Japanese public. He was again adopting a speaker-oriented approach and not a listener-oriented method. Asahi newspaper published an article titled "Hitori jyuuman en, dotanba no shuusei, shusoo no mentsu maru tsubure" (100,000 yen per person, last minute change, prime minister ends in utter failure) (Asahi Shinbun, April 16).

Now it is the time that Abe needs to realize that various economic monetary vouchers such as "Go to Travel" (Ryokoo ken), "Go to Eat" (Shokuji ken) are not the only kind of emergency plan that the Japanese people have been waiting for.

Additionally, Abe made the following statement claimed at the board meeting of his party (April 13, 2020).

(21) Kyuugyoo ni taishite hoshoo o okonatte iru kuni wa sekai ni rei ga naku, waga kuni no shien wa seikai de mottomo teatsui.

(There is no other country which offers better compensation to workers other than Japan. The compensation of our country is the best. Emphasis added)

We know that Japan has not offered the best worker compensation, as compared with other countries in the world ${ }^{10}$. Abe is simply using his own language and version of the facts to try to convince everyone ${ }^{11}$. This is further evidence that he is a speaker-oriented politician (unlike other foreign politicians such as German chancellor Angela Merkel, whose speech to the public was wellaccepted. In reference to Merkel's speech, Reuters (2020) printed an article titled "Merkel tells Germans: Fighting virus demands war-time solidarity" (Reuters, March 18). According to the article, Merkel, who addressed the nation for the first time in nearly 15 years in office (other than her annual New Year's address), said in her televised speech, that "since German reunification, actually, since World War Two, there has never been a challenge for our country in which acting in solidarity is so crucial" (emphasis added). As we see, the term solidarity has been the key concept for Merkel, which is very different from Abe's speaker-oriented style. ${ }^{12}$ Abe has never used the word "solidarity" in the same sense used by Merkel here - clear and unambiguous. In the same line, New Zealand prime minister Jacinda Ardern pleaded the people of her country to "act like you have

\footnotetext{
${ }^{10}$ Veteran lawmaker Ichiro Ozawa of the National Democratic Party made a comment on this issue in the Daily newspaper in 2020. Please see https://www.daily.co.jp/gossip/2020/04/15/0013273938. shtml. [Accessed 20 April 2020]

${ }^{11}$ Abe had said Japan would ramp up its PCR (polymerase chain reaction) testing capacity to 20,000 per day (April 6, 2020). However, among many health experts including well-known professor Shinji Shimada, president of the Yamanashi University, claims that the limited PCR testing system is "the shame for the country of Japan" and remains a santan taru jyookyoo (terribly miserable situation). Please see https://digital.asahi.com/articles/ASN555QVWN54UTIL02Q.html. [Accessed 30 April 2020]. Professor Kenji Shibuya of Kings College London who is the former senior advisor to the Director General of WHO (World Health Organization) advocates the nationwide PCR test system in Japan. Please see https://www.kcl.ac.uk/news/kings-welcomes-new-director-to-establishinstitute-for-population-health. [Accessed 8 April 2019]

${ }^{12}$ See Azuma (forthcoming) for the discussion of Japanese-Americans newspaper during World War Two.
} 
COVID-19." Right next to her was a huge billboard vividly stating "Unite against COVID-19," as she personally spoke to the audience, saying "you are not alone, you will hear us, see us daily as we guide New Zealand in this period." Again, the concept of unity or solidarity was the key message from her speech (The Guardian, $2020)^{13}$. Furthermore, the Atlantic newspaper also pointed out that her success “isn't all Ardern's doing; it's also the product of an impressive collective effort by public-health institutions, opposition politicians, and New Zealanders as a whole, who have largely abided by social-distancing restrictions (The Atlantic, 2020). In all, we can say that Ardern was very successful in maintaining the sense of solidarity and "togetherness" among the people of her country.

\section{Concluding Remarks}

In this paper, we have studied the language style used by politicians to attract support for their political agendas. Our focus was to examine how they behaved in doing so. Through our analysis, we have found two approaches; one is an orientation to the speaker (i.e., speaker-oriented style), and the other is an orientation to the listener/addressee (i.e., listener-oriented style). By studying the speeches of prime minister Abe Shinzo, we have realized that politicians can maximize their effectiveness when orienting their speech to listeners, instead of to the speaker. In doing so, listeners feel a sense of common purpose and a shared feeling of ownership. This knowledge sharing is a key concept in establishing grouporientation in politics. By enhancing a sense of solidarity, shared knowledge increases the ability for political dialogue to go beyond the mere structures of power.

In addition, we can also conclude that spoken language is more effective when it shares emotion/solidarity with its audience, instead of a detached delivery of facts or abstract propositions. This can be characterized as a sense of rapport-talk rather than a simple report-talk (Tannen, 1993) ${ }^{14}$. Human beings enjoy the sharing of information between and among themselves. Instead of monopolizing information for ourselves (i.e., speakers), we should prefer to share it with others (i.e., listeners) so that we can maximize the potential output.

Politicians, like any other profession, are interested in "sharing" and expanding their own knowledge with others. A listener-oriented approach that emphasizes an emotional connection or shared common ground with the constituents (more than just rote information, facts and propositions), will increase the likelihood of accomplishing political goals and objectives. In other words, focusing on rapporttalk and emphasizing emotion is an effective way for politicians to maximize their spoken language and have an impact on democratic institutions in Japan, as well

\footnotetext{
13"The Call to Unite" is a global livestream event to encourage the concept of solidarity among the people in the world so that they can fight against the COVID-19 in 2020. The event has been participated by more than 200 people including well-known politicians and entertainers.

${ }^{14}$ Tannen (1993) argues that "rapport-talk" is a communication style that promotes social affiliation and emotional connection and "report-talk" is a style focused on exchanging information with little emotional import.
} 
as other nations ${ }^{15}$. Tannen (2007) has highlighted several methods to enhance mutual understanding and involvement in speech, including repetition, dialogue, details, and storytelling, all of which pertain to personal emotions. Remarkably, none of these are actively used in Abe's speeches. Politicians, including Abe, seldom use any of these techniques to connect with their constituents, most often simply speaking "at" them and not "to" them. They frequently fail to communicate ideas in a shared emotive manner and consequently fail to move the audience toward a common joint connection ${ }^{16}$.

In sum, we argue that focusing more on listeners and paying attention to the emotional connection of speech (rather than a detached, fact-based, delivery of information), and conducting rapport-talk rather than report-talk with a sense of "solidarity," are effective ways to attract and gain support from the general public and the media. Finally, it is important to keep in mind that understanding and support is facilitated, even enabled, by a shared, emotional, interpersonal experience, or in one word, "rapport," which is exhibited in a listener-oriented speech style.

\section{Acknowledgments}

A part of this research was funded by the Faculty Fellow Award of the University of Utah (2021).

\section{References}

Abe, A. (2015). "Watashi” o ikiru. (I live myself). Tokyo: Kairyuusha.

Azuma, S. (2010). Senkyo Enzetsu no Gengogaku. (Linguistics of political speeches). Kyoto: Minerva Shoboo.

Azuma, S. (2014). The language of leadership in the aftermath of the Japanese earthquake. In A. Awotona (ed.), Rebuilding Sustainable Communities After Disasters in China, Japan and Beyond, 203-244. Newcastle upon Tyne: Cambridge Scholars Publishing.

Azuma, S. (2019). Political rhetoric in Japan. In A. Burkhardt (ed.), Handbuch Politische Rhetorik, 1131-1151. Berlin and Boston: Walter de Gruyter.

Azuma, S. (forthcoming). Japanese Americans and generational tension: a case of the ethnic press the Utah Nippoo during World War II. International Journal of the Sociology of Language.

Curtis, G. (2009). Daigishi no tanjoo. (Birth of a congressman). Tokyo: BP Press.

Decker, B. (2008). You've got to be believed to be heard. New York: St. Martin's Press.

Duranti, A. (1986). The audience as co-author. Text, 6(3), 239-247.

Ikeda, K. (2009). Audience participation through interjection. Journal of Language and Politics, 8(1), 52-71.

Lim, E. (2008). The anti-intellectual presidency. New York: Oxford University Press.

\footnotetext{
${ }^{15}$ For discussions about rhetorical styles among U.S. presidents, please see Ott and Dickinson (2019) and $\operatorname{Lim}(2008)$ among others.

${ }^{16}$ Duranti (1986) emphasizes the active role of the listener in interpreting and shaping a speaker's discourse.
} 
Makino, S. (1983). Speaker/Listener-orientation and formality marking in Japanese. Gengo Kenkyuu, 84, 126-145.

Makino, S. (2018). Nihongo o hoyaku suru to iu koto. (Translation of Japanese expressions). Tokyo: Chuukoo Shinsho.

Maynard, S. (1994). Images of involvement and integrity: rhetorical styles of a Japanese politician. Discourse and Society, 5(2), 233-261.

Okamoto, J. (2020). Naze Abe shushoo wa kisha kaiken de chi no kayotta kotoba o tsukawanai no $\mathrm{ka}$. (Why don't you use the common words at the Abe handwriting Japanese press conference). Retrieved from: https://president.jp/articles/-/34353. [Accessed 20 April 2020]

Ott, B., Dickinson, G. (2019). The twitter presidency. New York: Routledge.

Ozawa, I. (2020). Abe shushoo no kyuugyoo hoshoo o okonatte iru kuni wa rei ga nai ni "Nanika no jyoodan". (Abe's handwriting class fish Ohoshoo the example of the country where you are going is "somewhere"). Retrieved from: https://www.daily.co. jp/gossip/2020/04/15/0013273938.shtml. [Accessed 20 April 2020]

Reuters (2020). Merkel tells Germans: fighting virus demands war-time solidarity. Reuters.

Taniguchi, T. (2018). Abe shinzoo no shinjitsu. (The truth of Abe Shinzo). Tokyo: Gokuu Shuppan.

Tannen, D. (1993). Framing in discourse. New York: Oxford University Press.

Tannen, D. (2007). Talking voices: repetition, dialogue, and imagery in conversational discourse. Cambridge: Cambridge University Press.

The Atlantic (2020). New Zealand's Prime Minister may be the most effective leader on the planet. The Atlantic.

The Guardian (2020). Ardern urges New Zealanders to 'act like you have Covid-19' as lockdown looms. The Guardian. 
